\title{
High Cell Selectivity and Bactericidal Mechanism of Symmetric Peptides Centered on D-Pro-Gly Pairs
}

\author{
Boyan Jia ${ }^{1,+}$, Yiming Wang ${ }^{1,+}$, Ying Zhang ${ }^{1}$, Zi Wang ${ }^{2}$, Xue Wang ${ }^{1}$, Inam Muhammad ${ }^{1}$, \\ Lingcong Kong ${ }^{1}$, Zhihua Pei ${ }^{1}$, Hongxia Ma ${ }^{1, *}$ and Xiuyun Jiang ${ }^{1,3,4, *}$ \\ 1 College of Animal Science and Technology, Jilin Agricultural University, Xincheng Street No. \#2888, \\ Changchun 130118, China; jiaboyan@jlau.edu.cn (B.J.); wym27149@jlau.edu.cn (Y.W.); \\ zhangying147@jlau.edu.cn (Y.Z); wangxue@jlau.edu.cn (X.W.); dr.inam@sbbu.edu.pk (I.M.); \\ lingcong@jlau.edu.cn (L.K.); peizhihua@jlau.edu.cn (Z.P.) \\ 2 College of Animal Science and Technology, Inner Mongolia University for Nationalities, \\ Tongliao 028000, China; wangzi0225@jiau.edu.cn \\ 3 College of Life Science, Jilin Agricultural University, Xincheng Street No. \#2888, Changchun 130118, China \\ 4 College of Animal Science and Technology, Changchun Sci-Tech University, Changchun 130600, China \\ * Correspondence: mahongxia@jlau.edu.cn (H.M.); jiangxiuyun@jlau.edu.cn (X.J.) \\ + These authors contributed equally to this work.
}

Received: 1 January 2020; Accepted: 4 February 2020; Published: 8 February 2020

check for updates

\begin{abstract}
Antimicrobial peptides (AMPs) have a unique action mechanism that can help to solve global problems in antibiotic resistance. However, their low therapeutic index and poor stability seriously hamper their development as therapeutic agents. In order to overcome these problems, we designed peptides based on the sequence template XXRXXRRzzRRXXRXX-NH ${ }_{2}$, where $X$ represents a hydrophobic amino acid like Phe (F), Ile (I), and Leu (L), while zz represents Gly-Gly (GG) or D-Pro-Gly (pG). Showing effective antimicrobial activity against Gram-negative bacteria and low toxicity, designed peptides had a tendency to form an $\alpha$-helical structure in membrane-mimetic environments. Among them, peptide $\mathrm{LR}_{\mathrm{pG}}(\mathrm{X}: \mathrm{L}, \mathrm{zz}: \mathrm{pG})$ showed the highest geometric mean average treatment index $\left(\mathrm{GM}_{\mathrm{TI}}=73.1\right)$, better salt, temperature and $\mathrm{pH}$ stability, and an additive effect with conventional antibiotics. Peptide $\mathrm{LR}_{\mathrm{pg}}$ played the role of anti-Gram-negative bacteria through destroying the cell membrane. In addition, peptide $\mathrm{LR}_{\mathrm{pG}}$ also exhibited an anti-inflammatory activity by effectively neutralizing endotoxin. Briefly, peptide $L R_{p G}$ has the potential to serve as a therapeutic agent to reduce antibiotic resistance owing to its high therapeutic index and great stability.
\end{abstract}

Keywords: antimicrobial peptides; cell selectivity; stability; mechanism; endotoxin neutralization

\section{Introduction}

With the widespread use of antibiotics in clinical practice in recent years, the resistance rate of bacteria to traditional antibiotics is increasing. The development of antibacterial reagents with new antibacterial mechanisms is imminent [1]. As an important part of innate immunity, antimicrobial peptides (AMPs) form the first line of defense against antimicrobial infections, as found in many microorganisms including insects, plants, and animals [2]. Furthermore, AMPs are known for their anti-inflammatory properties, anti-biofilm formation, promotion of tissue and injury repair, and anti-cancer effects [2-4]. Compared to traditional antibiotics, AMPs exert an antibacterial effect through non-receptor-mediated membrane permeability. AMPs are expected to be alternatives to antibiotics because of their unique action mechanism [5-7]. Although more than 3000 AMPs were found, their application as therapeutic agents is seriously hindered due to some limiting factors including manufacturing costs, cytotoxicity, and poor stability [8]. 
The heptad repeat sequence is a repeat sequence composed of seven amino acids, where the "a" and " $\mathrm{d}$ " positions are occupied by hydrophobic amino acids [9]. It was found that natural AMPs possessing heptad repeat sequences have great antibacterial and anti-inflammatory activity, but their application is hindered by high cytotoxicity $[10,11]$. Previous studies mostly focused on how different hydrophobic amino acids at the "a" and " $\mathrm{d}$ " positions influence antibacterial activity and cytotoxicity of AMPs, but few studies used this sequence element to design new AMPs [12,13]. Some papers showed that symmetric AMPs centered on Gly-Gly (GG) or D-Pro-Gly (pG) have good antibacterial activity and high cell selectivity [14-17]. Therefore, we wondered if the same effect could be achieved when GG or $\mathrm{PG}$ was introduced into two symmetric heptad repeat sequences.

In this study, two symmetric heptad repeat sequences were connected by a short loop, and the sequence was designed as XXRXXRRzzRRXXRXX-NH ${ }_{2}$, where $X$ represents Phe (F), Ile (I), and Leu (L), while zz represents Gly-Gly (GG) or D-Pro-Gly (pG). The net charge was +6 and the hydrophobicity was $40 \%-60 \%$, which is consistent with the statistical information on natural AMPs $[2,18]$. Hydrophobic amino acids F, I, and L were used to damage microbial cell membranes [19]. Flexible (GG) and rigid $(\mathrm{pG})$ loops were selectively inserted into the middle of two symmetric heptad repeat sequences to enhance cell selectivity $[17,20]$. In addition, $\operatorname{Arg}(R)$ was selectively introduced into the sequence template. The guanidine side chain of $\mathrm{R}$ allows it to form strong bidentate $\mathrm{H}$-bonds with the phosphate moiety of lipid head groups, thereby enhancing the electrostatic action between peptides and anionic bacterial membranes [20]. To determine the role of loops in the designed peptides, a control peptide was designed as a heptad repeat sequence as follows: the central $p G$ loop of peptide $L_{\mathrm{pG}}$ with highest cell selectivity was removed, and Leu located at the N-terminus and C-terminus of the peptide was exchanged with Gly and D-Pro, respectively. The positive charge and hydrophobicity were consistent with $\mathrm{LR}_{\mathrm{pG}}$. Finally, by amidating the C-terminus of the peptides, the charge of the AMPs was increased, and the stability of the structure was improved [21-23]. Using this method of designing and optimizing AMPs, we obtained $\mathrm{LR}_{\mathrm{pG}}(\mathrm{X}: \mathrm{L}, \mathrm{zz}: \mathrm{pG})$ with high cell selectivity and good conditional stability. The antibacterial mechanism study demonstrated that $L R_{p G}$ played the role of an anti-Gram-negative bacterial agent through destroying the cell membrane.

\section{Results}

\subsection{Peptide Design and Characteristics}

In this study, two symmetric heptad repeat sequences were connected by a short loop, and the sequence was designed as XXRXXRRzzRRXXRXX-NH $\mathrm{N}_{2}$ (X represents $\mathrm{F}$, I, and L; zz represents GG or $\mathrm{pG}$ ). The molecular mass of all peptides was consistent with theoretical values through measurement, demonstrating that the peptides were successfully synthesized. The hydrophobicity order of the designed peptides was as follows: $\mathrm{IR}_{\mathrm{pG}}>\mathrm{FR}_{\mathrm{pG}}>\mathrm{IR}_{\mathrm{GG}}>\mathrm{FR}_{\mathrm{GG}}=\mathrm{LR}_{\mathrm{pG}}=\mathrm{LR} \alpha>\mathrm{LR}_{\mathrm{GG}}$ (Table 1). MALDI-TOF MS of the designed peptides is shown in Supplementary Figure S1, and HPLC spectra of the designed peptides is shown in Supplementary Figure S2.

Table 1. Peptides and their key physicochemical parameters.

\begin{tabular}{|c|c|c|c|c|c|c|}
\hline Peptides & Sequence & Theoretical MW & Measured MW ${ }^{1}$ & Net Charge & $\mathrm{H}^{2}$ & $\mu \mathrm{Hre}^{3}$ \\
\hline $\mathrm{IR}_{\mathrm{GG}}$ & IIRIIRRGGRRIIRII-NH ${ }_{2}$ & 1974.52 & 1973.5 & 6 & 0.521 & 0.770 \\
\hline $\mathrm{IR}_{\mathrm{pG}}$ & IIRIIRRp ${ }^{4}$ GRRIIRII-NH ${ }_{2}$ & 2014.58 & 2013.8 & 6 & 0.566 & 0.800 \\
\hline $\mathrm{FR}_{\mathrm{GG}}$ & FFRFFRRGGRRFFRFF-NH ${ }_{2}$ & 2246.66 & 2245.68 & 6 & 0.516 & 0.767 \\
\hline $\mathrm{FR}_{\mathrm{pG}}$ & FFRFFRRp ${ }^{4}$ GRRFFRFF- $\mathrm{NH}_{2}$ & 2286.72 & 2285.74 & 6 & 0.561 & 0.797 \\
\hline $\mathrm{LR}_{\mathrm{GG}}$ & LLRLLRRGGRRLLRLL-NH ${ }_{2}$ & 1974.52 & 1973.51 & 6 & 0.471 & 0.743 \\
\hline $\mathrm{LR}_{\mathrm{pG}}$ & LLRLLRRp $^{4}$ GRRLLRLL-NH ${ }_{2}$ & 2014.58 & 2013.58 & 6 & 0.516 & 0.773 \\
\hline $\operatorname{LR} \alpha$ & GLRLLRRLLRRLLRLp $^{4}-\mathrm{NH}_{2}$ & 2014.58 & 2013.58 & 6 & 0.516 & 0.735 \\
\hline
\end{tabular}

${ }^{1}$ Molecular weight (MW) was determined by mass spectrometry (MS). ${ }^{2}$ The mean hydrophobicity (H) is the total hydrophobicity (sum of all residue hydrophobicity indices) divided by the number of residues. ${ }^{3}$ The relative hydrophobic moment of a peptide is its hydrophobic moment relative to that of a perfectly amphiphilic peptide. ${ }^{4}$ Lowercase letters indicate the D-enantiomer of the proline. 


\subsection{Circular Dichroism (CD) Spectroscopy}

The secondary structure of the designed peptides was detected using CD spectra in $10 \mathrm{mM}$ phosphate-buffered saline (PBS), 50\% trifluoroethanol (TFE), and $30 \mathrm{mM}$ sodium dodecyl sulfate (SDS). In $10 \mathrm{mM}$ PBS, the six designed peptides containing a central loop exhibited disordered conformations, and the control LR $\alpha$ showed a more ordered conformation. In 50\% TFE (mimicking the hydrophobic environment of the microbial membrane) and $30 \mathrm{mM}$ SDS (environment comparable to a negatively charged prokaryotic membrane) [15], $\mathrm{FR}_{\mathrm{GG}}, \mathrm{FR}_{\mathrm{pG}}, \mathrm{IR}_{\mathrm{GG}}$, and $\mathrm{IR}_{\mathrm{pG}}$ showed disordered conformations. $\mathrm{LR}_{\mathrm{pG}}$ and $\mathrm{LR}_{\mathrm{GG}}$ had a tendency to form an $\alpha$-helical structure with negative peaks at approximately $205 \mathrm{~nm}$ and $220 \mathrm{~nm}$. In contrast, although the hydrophobic and net charges of the control peptide $\mathrm{LR} \alpha$ were consistent with $\mathrm{LR}_{\mathrm{pG}}$, a typical $\alpha$-helical structure with negative peaks at approximately $208 \mathrm{~nm}$ and $222 \mathrm{~nm}$ was observed (Figure 1). The results reveled that the central loop (pG or GG) disrupted the formation of the $\alpha$-helical structure. The helical wheel projections of $\mathrm{LR}_{\mathrm{GG}}$, $\mathrm{LR}_{\mathrm{pG}}$, and $\mathrm{LR} \alpha$ are shown in Supplementary Figure S3.

\subsection{Antimicrobial Activity}

The antimicrobial activity of designed peptides is summarized in Table 2. The designed peptides showed better antimicrobial activity against Gram-negative bacteria than Gram-positive bacteria. For Gram-negative bacteria, $\mathrm{LR}_{\mathrm{pG}}$ showed the best antimicrobial activity among the six designed peptides containing a central loop $\left(\mathrm{LR}_{\mathrm{pG}}>\mathrm{LR}_{\mathrm{GG}}>\mathrm{FR}_{\mathrm{pG}}>\mathrm{FR}_{\mathrm{GG}}>\mathrm{IR}_{\mathrm{pG}}>\mathrm{IR}_{\mathrm{GG}}\right)$, and the lowest geometric mean minimal inhibitory concentration $\left(\mathrm{GM}_{\mathrm{MIC}}\right)$ value of $3.5 \mu \mathrm{M}$. The control peptide $L R \alpha$ exhibited antimicrobial activity that was a little better than $L_{p G}$ with a $G_{M}$ MIC value of $3 \mu \mathrm{M}$. For Gram-positive bacteria, peptides $\mathrm{LR}_{\mathrm{ZZ}}$ and $\mathrm{FR}_{\mathrm{ZZ}}$ had a relatively weaker antimicrobial effect compared to the control peptide LR $\alpha$ (Table 2).

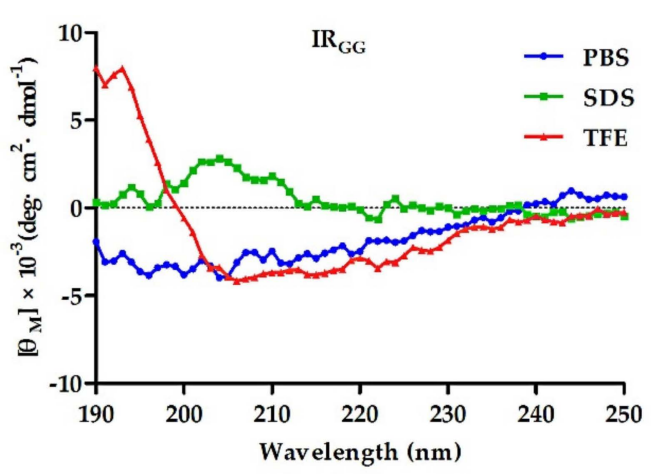

(a)

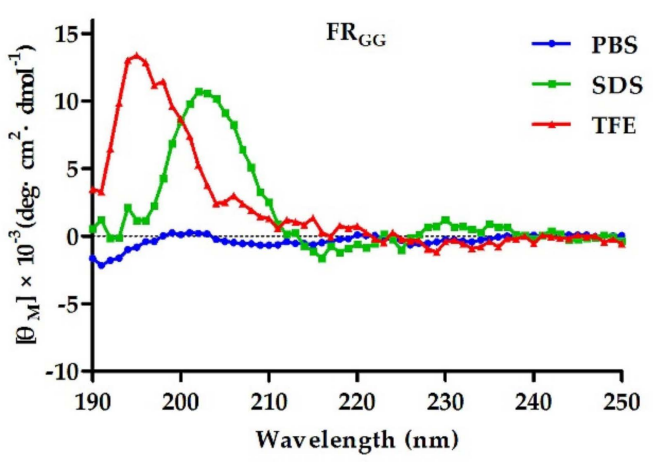

(c)

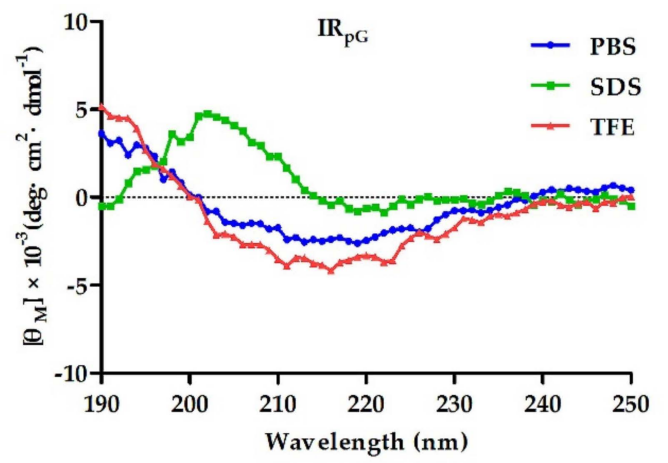

(b)

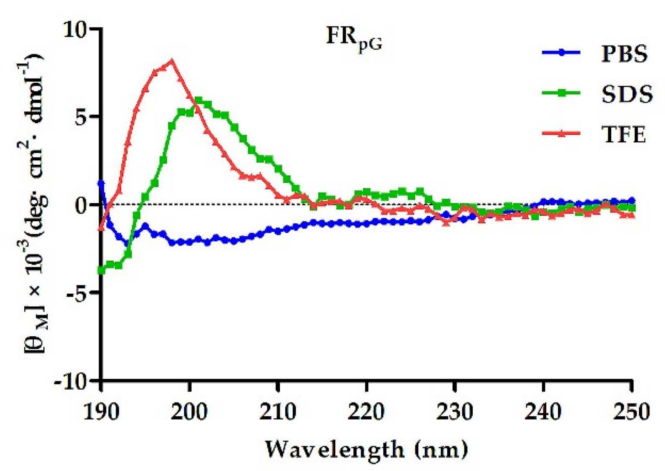

(d)

Figure 1. Cont. 


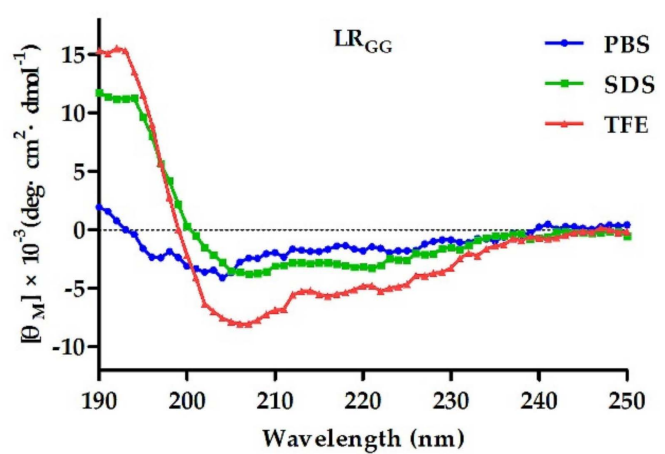

(e)

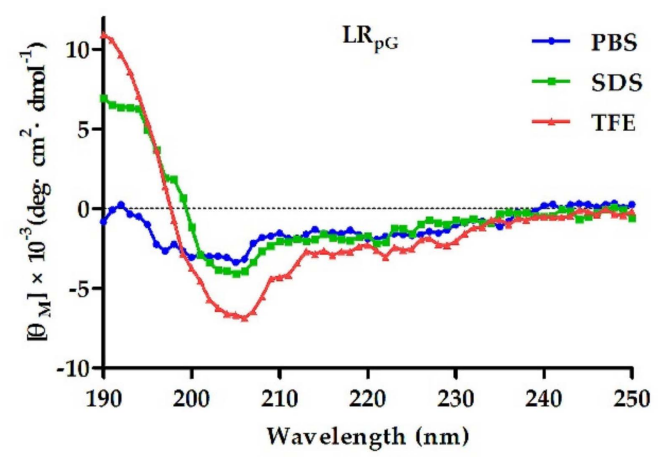

(f)

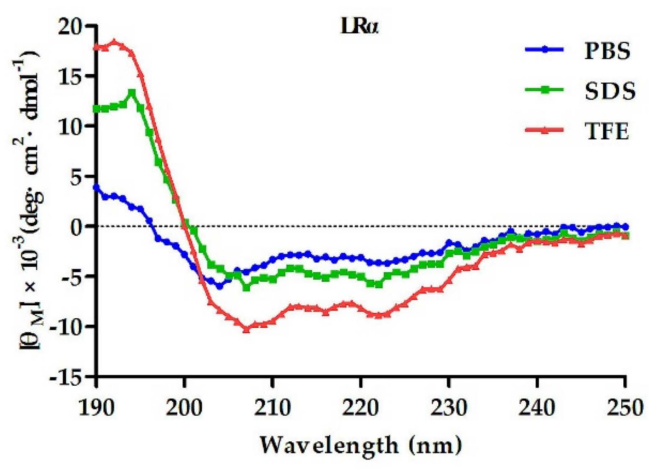

(g)

Figure 1. The circular dichroism (CD) spectra of (a) $\mathrm{IR}_{\mathrm{GG}},(\mathbf{b}) \mathrm{IR}_{\mathrm{pG}},(\mathbf{c}) \mathrm{FR}_{\mathrm{GG}},(\mathrm{d}) \mathrm{FR}_{\mathrm{pG}},(\mathbf{e}) \mathrm{LR}_{\mathrm{GG}}$, (f) $\mathrm{LR}_{\mathrm{pG}}$, and (g) $\mathrm{LR} \alpha$ were dissolved in $10 \mathrm{mM}$ phosphate-buffered saline (PBS) (blue), $30 \mathrm{mM}$ sodium dodecyl sulfate (SDS) (green), and 50\% trifluoroethanol (TFE) (red). The average value after three scans of every sample is shown. The CD spectrum of the buffer was subtracted.

Table 2. Minimum inhibitory concentrations (MICs) $(\mu \mathrm{M})$ and therapeutic index (TI) of the designed peptides.

\begin{tabular}{|c|c|c|c|c|c|c|c|c|}
\hline Bacterial Species & $\mathbf{I R}_{\mathrm{GG}}$ & $\mathbf{I R}_{\mathrm{pG}}$ & $\mathbf{F R}_{\mathrm{GG}}$ & $\mathrm{FR}_{\mathrm{pG}}$ & $\mathbf{L R}_{\mathrm{GG}}$ & $\mathbf{L R}_{\mathrm{pG}}$ & $\mathrm{LR} \alpha$ & Melittin \\
\hline \multicolumn{9}{|l|}{$\mathrm{MIC}(\mu \mathrm{M})$} \\
\hline \multicolumn{9}{|l|}{ Gram (-) } \\
\hline Escherichia coli ATCC25922 & 8 & 4 & 8 & 8 & 2 & 2 & 2 & 1 \\
\hline E. coli $\mathrm{K} 88$ & 16 & 16 & 16 & 8 & 4 & 2 & 4 & 2 \\
\hline Salmonella Pullorum NCTC5776 & 32 & 16 & 16 & 16 & 4 & 4 & 2 & 2 \\
\hline Klebsiella pneumonia CMCC46117 & 32 & 32 & 16 & 16 & 8 & 4 & 4 & 4 \\
\hline \multicolumn{9}{|l|}{$\operatorname{Gram}(+)$} \\
\hline Staphylococcus aureus ATCC25923 & $>128$ & $>128$ & 32 & 16 & 16 & 16 & 4 & 2 \\
\hline S. aureus ATCC29213 & $>128$ & $>128$ & 16 & 16 & 16 & 16 & 8 & 1 \\
\hline S. aureus ATCC 43300 & $>128$ & $>128$ & 32 & 32 & 32 & 16 & 8 & 2 \\
\hline Enterococcus faecalis ATCC29212 & $>128$ & $>128$ & 32 & 32 & 32 & 32 & 16 & 1 \\
\hline \multicolumn{9}{|l|}{$\mathrm{GM}^{1}(\mu \mathrm{M})$} \\
\hline Gram (-) & 21.1 & 16 & 16 & 13.9 & 4.6 & 3.5 & 3 & 2 \\
\hline Gram (+) & 256 & 256 & 26.9 & 22.6 & 22.6 & 19.0 & 8 & 1.4 \\
\hline $\mathrm{MHC}_{10}{ }^{2}(\mu \mathrm{M})$ & 512 & 512 & 128 & 128 & 256 & 256 & 4 & 0.25 \\
\hline \multicolumn{9}{|l|}{$\mathrm{TI}^{3}$} \\
\hline TI $(-)$ & 24.2 & 32 & 8 & 9.2 & 55.6 & 73.1 & 1.3 & 0.125 \\
\hline $\mathrm{TI}(+)$ & 2 & 2 & 4.8 & 5.7 & 11.2 & 13.5 & 0.5 & 0.178 \\
\hline
\end{tabular}

${ }^{1}$ Geometric mean (GM) of MICs for the nine strains was measured. A value of $256 \mu \mathrm{M}$ was used for the TI when no antimicrobial activity was examined at $128 \mu \mathrm{M} .{ }^{2}$ Minimum hemolysis concentration $10 \%\left(\mathrm{MHC}_{10}\right)$ was characterized as the lowest concentration inducing $10 \%$ hemolysis. ${ }^{3} \mathrm{TI}$ was calculated as $\mathrm{MHC}_{10} / \mathrm{GM}$. 


\subsection{Biocompatibility Assays}

The hemolytic activity of designed peptides against human red blood cells (hRBCs) was determined in a range of 1-512 $\mu \mathrm{M}$. The $\mathrm{MHC}_{10}$ values of $\mathrm{IR}_{\mathrm{GG}}, \mathrm{IR}_{\mathrm{pG}}, \mathrm{FR}_{\mathrm{GG}}, \mathrm{FR}_{\mathrm{pG}}, \mathrm{LR}_{\mathrm{GG}}, \mathrm{LR}_{\mathrm{pG}}$, and $\mathrm{LR} \alpha$ were $512 \mu \mathrm{M}, 512 \mu \mathrm{M}, 128 \mu \mathrm{M}, 128 \mu \mathrm{M}, 256 \mu \mathrm{M}, 256 \mu \mathrm{M}$, and $4 \mu \mathrm{M}$, respectively (Figure 2a). In general, the cytotoxicity of the designed peptides was consistent with the hemolytic activity. Later on, the murine macrophage cell line (RAW 264.7) and human embryonic kidney cells (HEK293T) were treated with $64 \mu \mathrm{M}$ peptides, and the cell survival rate of RAW 264.7 cells was as follows: $\operatorname{IR}_{\mathrm{pG}}(98 \%)>\operatorname{IR}_{\mathrm{GG}}(95 \%)>\mathrm{LR}_{\mathrm{pG}}(92 \%)>\mathrm{LR}_{\mathrm{GG}}(84 \%)>\mathrm{FR}_{\mathrm{pG}}(78 \%)>\mathrm{FR}_{\mathrm{GG}}(66 \%)$ (Figure 2b). Similarly, the cell survival rate of HEK293T cells was as follows: $\operatorname{IR}_{\mathrm{pG}}(98 \%)>\mathrm{IR}_{\mathrm{GG}}$ $(96 \%)>\mathrm{LR}_{\mathrm{pG}}(93 \%)>\mathrm{LR}_{\mathrm{GG}}(91 \%)>\mathrm{FR}_{\mathrm{pG}}(85 \%)>\mathrm{FR}_{\mathrm{GG}}(76 \%)$ (Supplementary Figure S4). However, the cell survival rate of both cells treated with $\mathrm{LR} \alpha$ was less than $10 \%$. To determine the cell selectivity of the designed peptide, the therapeutic index (TI) $\left(\mathrm{MHC}_{10} / \mathrm{GM}_{\mathrm{MIC}}\right)$ of each peptide was calculated. Among all tested peptides, $\mathrm{LR}_{\mathrm{pG}}$ showed the highest $\mathrm{GM}_{\mathrm{TI}}$ (73.1) against Gram-negative bacteria (Table 2).

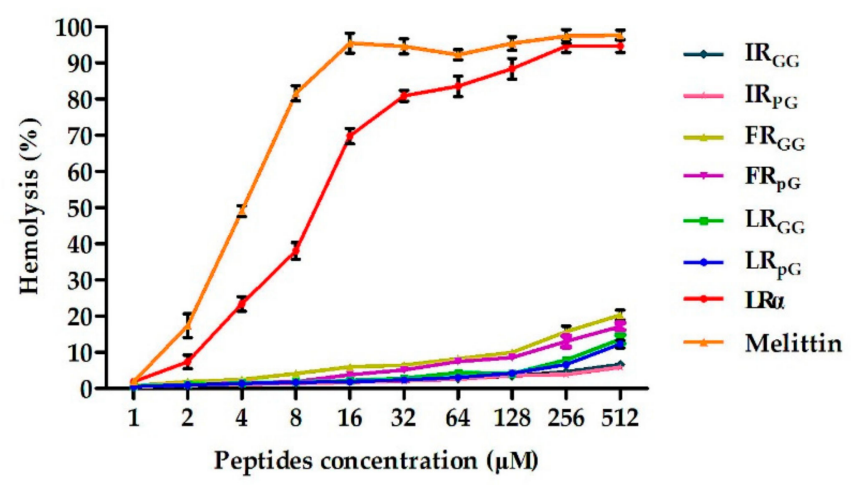

(a)

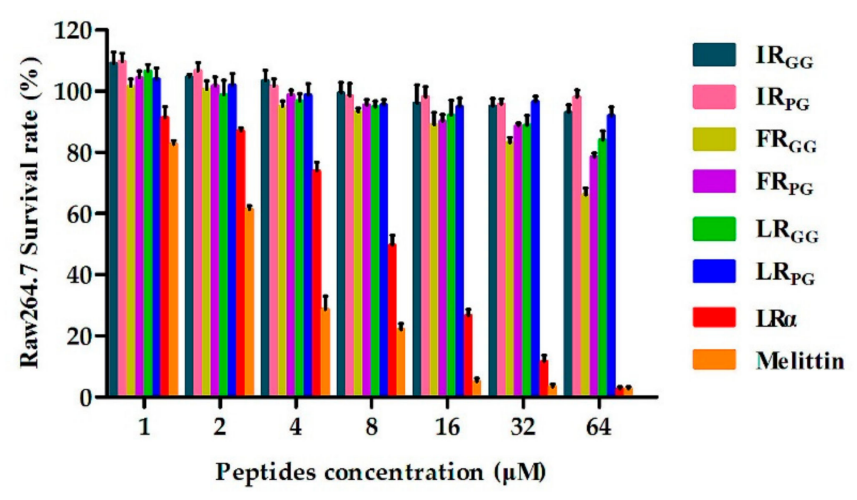

(b)

Figure 2. (a) Hemolytic activity of designed peptides against human red blood cells (hRBCs); (b) cytotoxicity of the designed peptides against RAW 264.7 cells. The diagrams are based on at least three independent experiments.

\subsection{Condition Sensitivity Assays}

These results demonstrated that $\mathrm{LR}_{\mathrm{pG}}$ could maintain antimicrobial activity in different conditions. Therefore, $\mathrm{LR}_{\mathrm{pG}}$ may have good potential in clinical application (Tables 3 and 4). 


\subsection{Additive Effect of AMPs and Conventional Antibiotics}

Based on the MICs of the designed peptides and antibiotics, the antimicrobial interactions of peptides and antibiotics were determined using a checkerboard assay. The combination of $\mathrm{LR}_{\mathrm{pG}}$ and streptomycin exerted a synergistic effect against Escherichia coli ATCC25922. The fractional inhibitory concentration index (FICI) value was 0.5 , while the combination of $\mathrm{LR}_{\mathrm{pG}}$ with other conventional antibiotics produced an additive effect with FICI values from 0.625 to 1 (Table 5).

Table 3. The MICs $(\mu \mathrm{M})$ of the designed peptides against E. coli ATCC25922 in the presence of physiological salts.

\begin{tabular}{cccccccc}
\hline \multirow{2}{*}{ Peptides } & \multirow{2}{*}{ Control $^{\mathbf{1}}$} & \multicolumn{5}{c}{ Physiological Salts $^{2}$} \\
\cline { 3 - 7 } & & $\mathbf{N a C l}$ & $\mathbf{K C l}$ & $\mathbf{N H}_{\mathbf{4}} \mathbf{C l}$ & $\mathbf{M g C l}_{\mathbf{2}}$ & $\mathbf{Z n C l}_{\mathbf{2}}$ & $\mathbf{F e C l}_{\mathbf{3}}$ \\
\hline $\mathrm{IR}_{\mathrm{GG}}$ & 8 & 64 & 8 & 8 & 16 & 16 & 8 \\
$\mathrm{IR}_{\mathrm{pG}}$ & 4 & 32 & 4 & 4 & 8 & 4 & 4 \\
$\mathrm{FR}_{\mathrm{GG}}$ & 8 & 64 & 8 & 8 & 16 & 16 & 8 \\
$\mathrm{FR}_{\mathrm{pG}}$ & 8 & 32 & 8 & 8 & 8 & 8 & 8 \\
$\mathrm{LR}_{\mathrm{GG}}$ & 2 & 8 & 2 & 2 & 4 & 2 & 2 \\
$\mathrm{LR}_{\mathrm{pG}}$ & 2 & 8 & 2 & 2 & 2 & 2 & 2 \\
$\mathrm{LR} \alpha$ & 2 & 8 & 2 & 2 & 2 & 2 & 2 \\
Melittin & 1 & 4 & 1 & 1 & 1 & 1 & 1 \\
\hline
\end{tabular}

${ }^{1}$ The control MICs were determined in Mueller-Hinton broth MHB medium without physiological salts. ${ }^{2}$ The final physiological concentrations of $\mathrm{NaCl}, \mathrm{KCl}, \mathrm{NH}_{4} \mathrm{Cl}, \mathrm{MgCl}_{2}, \mathrm{ZnCl}_{2}$, and $\mathrm{FeCl}_{3}$ were $150 \mathrm{mM}, 4.5 \mathrm{mM}, 6 \mu \mathrm{M}, 1 \mathrm{mM}$, $8 \mu \mathrm{M}$, and $4 \mu \mathrm{M}$, respectively. The data are based on at least three independent experiments.

Table 4. The MICs $(\mu \mathrm{M})$ of the designed peptides against E. coli ATCC25922 after temperature and $\mathrm{pH}$ treatment.

\begin{tabular}{lcccccccc}
\hline \multirow{2}{*}{ Peptides Control (pH 7) } & \multicolumn{3}{c}{ Temperature } & \multicolumn{5}{c}{$\mathbf{p H}$} \\
\cline { 2 - 8 } & & $\mathbf{0}{ }^{\circ} \mathbf{C}$ & $\mathbf{3 7}{ }^{\circ} \mathbf{C}$ & $\mathbf{1 0 0}{ }^{\circ} \mathbf{C}$ & $\mathbf{p H ~ 4}$ & $\mathbf{p H ~ 6}$ & $\mathbf{p H ~ 8}$ & $\mathbf{p H ~ 1 0}$ \\
\hline $\mathrm{IR}_{\mathrm{GG}}$ & 8 & 8 & 8 & 8 & 16 & 8 & 8 & 16 \\
$\mathrm{IR}_{\mathrm{pG}}$ & 4 & 4 & 4 & 4 & 16 & 4 & 8 & 16 \\
$\mathrm{FR}_{\mathrm{GG}}$ & 8 & 8 & 8 & 8 & 32 & 8 & 8 & 32 \\
$\mathrm{FR}_{\mathrm{pG}}$ & 8 & 8 & 8 & 8 & 16 & 8 & 8 & 32 \\
$\mathrm{LR}_{\mathrm{GG}}$ & 2 & 2 & 2 & 2 & 2 & 2 & 2 & 4 \\
$\mathrm{LR}_{\mathrm{pG}}$ & 2 & 2 & 2 & 2 & 2 & 2 & 2 & 4 \\
$\mathrm{LR} \alpha$ & 2 & 2 & 2 & 2 & 2 & 2 & 2 & 4 \\
$\mathrm{Melittin}$ & 1 & 1 & 1 & 1 & 2 & 1 & 1 & 2 \\
\hline
\end{tabular}

Table 5. The fractional inhibitory concentration index (FICI $)^{1}$ for $\mathrm{LR}_{\mathrm{pG}}$ in combination with conventional antibiotics against E. coli ATCC25922.

\begin{tabular}{ccccc}
\hline Peptide & Streptomycin $^{2}$ & Ciprofloxacin $^{2}$ & Chloramphenicol $^{2}$ & Cefotaxime $^{2}$ \\
\hline $\mathrm{LR}_{\mathrm{pG}}$ & 0.5 & 0.625 & 0.75 & 1 \\
\hline
\end{tabular}

${ }^{1} \mathrm{FICI} \leq 0.5$ denotes synergy, $0.5<\mathrm{FICI} \leq 1.0$ denotes additive, and $1.0<\mathrm{FICI} \leq 4.0$ denotes indifferent. ${ }^{2}$ The $\mathrm{MICs}$ of streptomycin, ciprofloxacin, chloramphenicol, and cefotaxime against E. coli ATCC25922 were $2 \mu \mathrm{M}, 8 \mu \mathrm{M}, 8 \mu \mathrm{M}$, and $2 \mu \mathrm{M}$, respectively.

\subsection{Antimicrobial Mechanism Study}

\subsubsection{Outer Membrane Permeability Assay}

Most AMPs kill bacteria by destroying the bacterial cell membrane. Since the outer membrane of the cell is negatively charged at physiological $\mathrm{pH}$, the permeability of the cationic AMPs to the outer membrane is increased [21]. The permeability of peptides to the Gram-negative bacterial outer 
membrane can be reflected by N-phenyl-1-naphthylamine (NPN) uptake $[15,17,21]$. NPN is normally excluded from the outer membrane; however, once the outer membrane is permeabilized, NPN is taken up intracellularly and shows increased fluorescence. As shown in Figure 3, $\mathrm{LR}_{\mathrm{pG}}$ and $\mathrm{LR} \alpha$ were able to permeabilize the outer membrane of E. coli ATCC25922 at concentrations from 1 to $32 \mu \mathrm{M}$ in a concentration-dependent manner. At peptide concentrations greater than $8 \mu \mathrm{M}$, the outer membrane permeability induced by $\mathrm{LR}_{\mathrm{pG}}$ and $\mathrm{LR} \alpha$ was over $75 \%$. Moreover, the outer membrane permeability induced by $L R \alpha$ was slightly stronger than that induced by $L_{p G}$ at the same concentration.

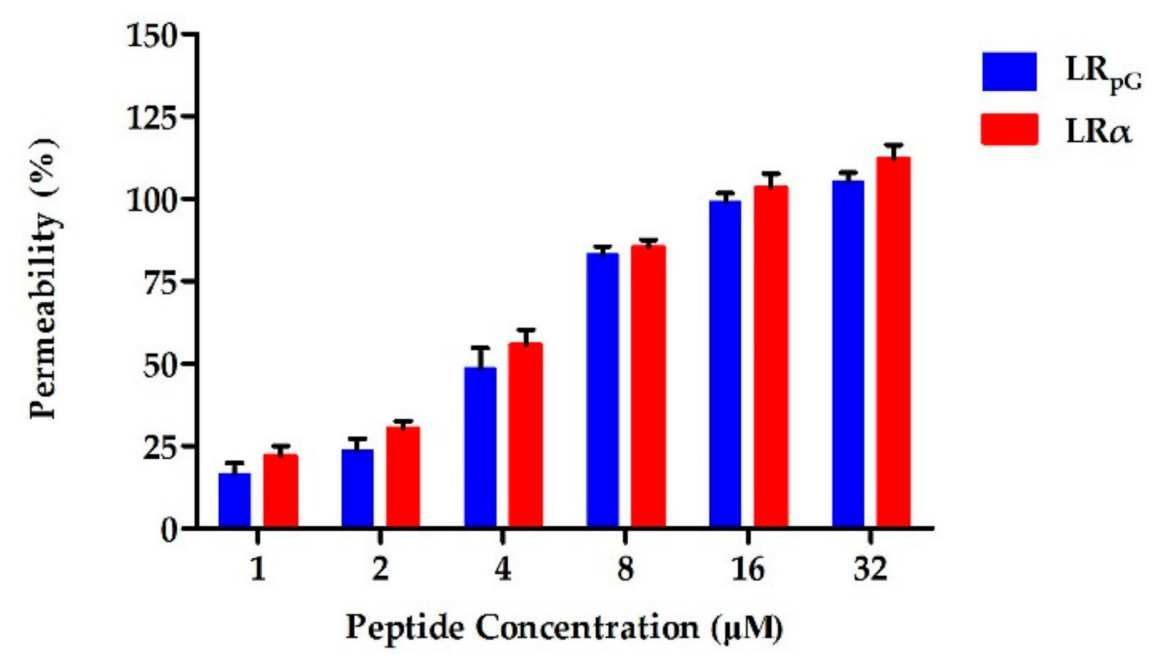

Figure 3. Outer membrane permeability of $\mathrm{LR}_{\mathrm{pG}}$ and $\mathrm{LR} \alpha$ at the concentrations from 1 to $32 \mu \mathrm{M}$. The diagram is based on at least three independent experiments.

\subsubsection{Inner Membrane Permeability Assay}

The $\mathrm{LR}_{\mathrm{pG}}$ permeability to the Gram-negative bacterial inner membrane was determined by measuring the cytoplasm $\beta$-galactosidase activity. $\mathrm{LR}_{\mathrm{pG}}$ and $\mathrm{LR} \alpha$ were able to induce an increase in the inner membrane permeability from 0 to $40 \mathrm{~min}$. However, $\mathrm{LR} \alpha$ displayed an optical density value at $420 \mathrm{~nm}\left(\mathrm{OD}_{420}\right)$ much higher than $\mathrm{LR}_{\mathrm{pG}}$ at the same point in time. This phenomenon was different from the results of outer membrane permeability (Figure 4).

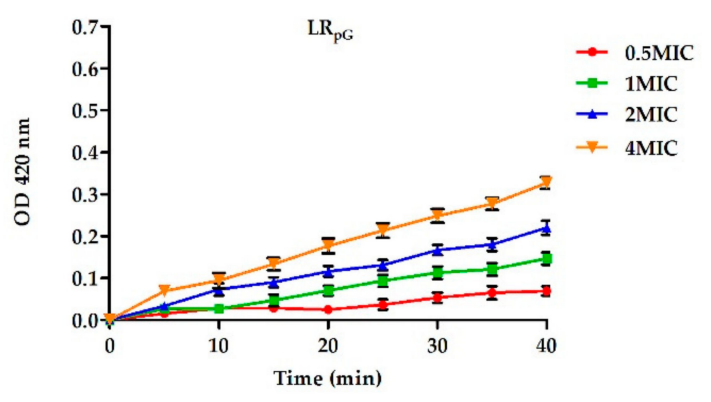

(a)

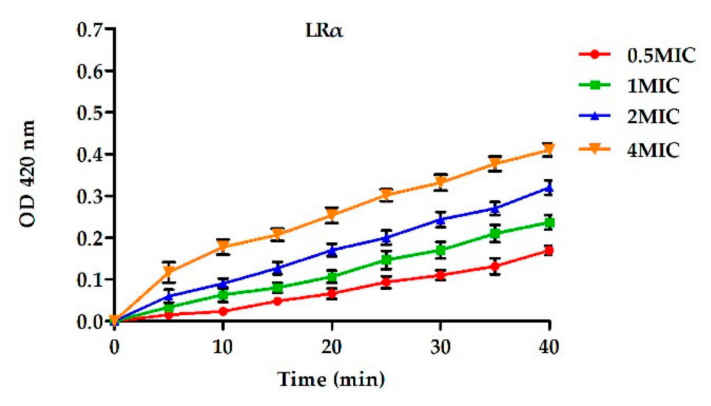

(b)

Figure 4. Inner membrane permeability of (a) $\mathrm{LR}_{\mathrm{pG}}$ and (b) $\mathrm{LR} \alpha$ at different concentrations. The diagrams are based on at least three independent experiments.

\subsubsection{Cytoplasmic Membrane Depolarization}

In addition to inner and outer membrane permeability, changes in the plasma membrane potential energy of $E$. coli ATCC25922 were determined using 3,3'-dipropylthiadicarbocyanine ( $\mathrm{diSC}_{3}-5$ ). The depolarization ability of cell membranes induced by $L R_{p G}$ and $L R \alpha$ was dose- and time-dependent 
over $1500 \mathrm{~s}$ of measured time. This experiment showed that $\mathrm{LR} \alpha$ had a faster and stronger depolarization ability than $\mathrm{LR}_{\mathrm{pG}}$ (Figure 5).

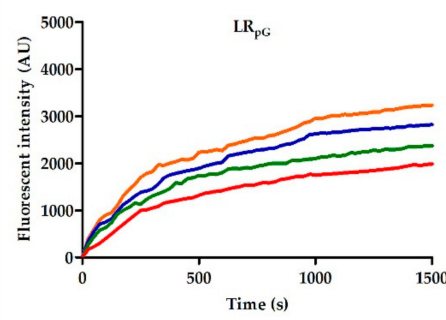

(a)

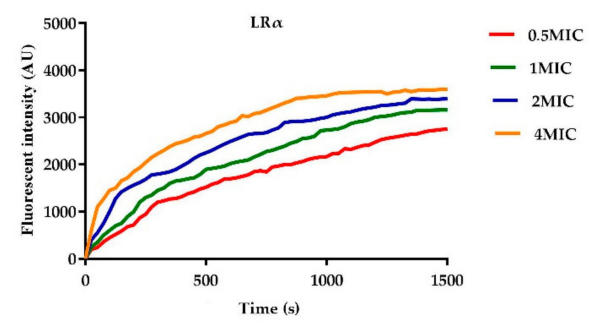

(b)

Figure 5. Cytoplasmic membrane potential variation of $E$. coli ATCC25922 treated with (a) $L_{\mathrm{pG}}$ and (b) $\mathrm{LR} \alpha$ at different levels of concentration. The diagram is based on at least three independent experiments.

\subsubsection{Scanning Electron Microscopy (SEM)}

The cell morphology and membrane damage of E. coli ATCC25922 after LR $_{\mathrm{pG}}$ and melittin treatment were observed by SEM. In the control group, E. coli cells had a smooth and bright surface (Figure 6a), while those treated with peptides showed a rough surface with blebbing, as well as shrunken and destroyed shapes. The effect observed in the SEM micrographs was stronger in the cells treated with $\mathrm{LR}_{\mathrm{pG}}$ than with the control (Figure $\left.6 \mathrm{~b}, \mathrm{c}\right)$.

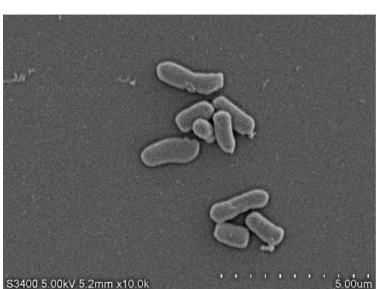

(a)

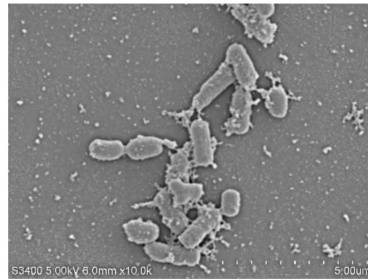

(b)

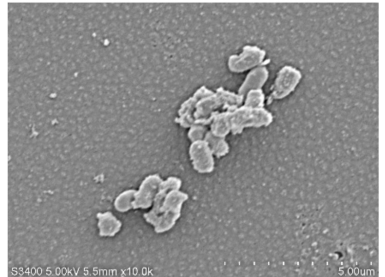

(c)

Figure 6. SEM micrographs of E. coli ATCC25922: (a) control; (b) $\mathrm{LR}_{\mathrm{pG}}$-treated; (c) LR $\alpha$-treated.

\subsubsection{DNA Binding Assay}

The antibacterial effects of AMPs are exerted not only by acting on cell membranes, but also by binding to intracellular substances, such as DNA. Therefore, the ability to induce intracellular effects was measured using a DNA binding analysis. As shown in Figure 7, $\mathrm{LR}_{\mathrm{pG}}$ and $\mathrm{LR} \alpha$ exhibited binding ability at $64 \mu \mathrm{M}$ and $16 \mu \mathrm{M}$, respectively. This experiment showed that $\mathrm{LR} \alpha$ had a stronger DNA binding ability than $\mathrm{LR}_{\mathrm{pG}}$.

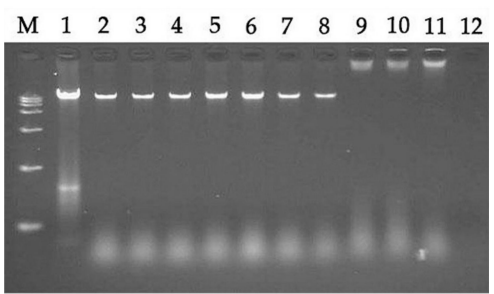

(a)

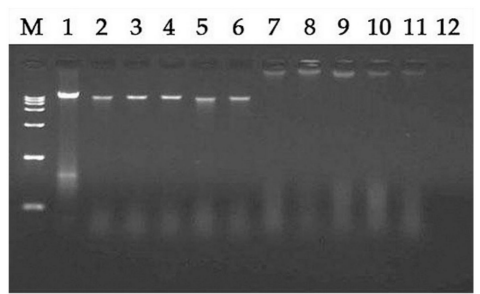

(b)

Figure 7. A gel retardation experiment was used to measure the DNA binding assay: (a) $\mathrm{LR}_{\mathrm{pG}}$-treated; (b) LR $\alpha$-treated. M: DNA marker alone; 1: genomic DNA alone; 2: with $0.5 \mu \mathrm{M}$ peptide; 3: with $1 \mu \mathrm{M}$ peptide; 4: with $2 \mu \mathrm{M}$ peptide; 5: with $4 \mu \mathrm{M}$ peptide; 6: with $8 \mu \mathrm{M}$ peptide; 7: with $16 \mu \mathrm{M}$ peptide; 8: with $32 \mu \mathrm{M}$ peptide; 9: with $64 \mu \mathrm{M}$ peptide; 10: with $128 \mu \mathrm{M}$ peptide; 11: with $256 \mu \mathrm{M}$ peptide; 12: $256 \mu \mathrm{M}$ peptide alone. 


\subsubsection{Lipopolysaccharide (LPS) Binding Assay}

To detect the binding ability between peptides and LPS, the secondary structure of the peptides was measured using the CD spectrum in different concentrations of LPS. As shown in Figure 8, in $10 \mathrm{mM}$ PBS without LPS solution, $\mathrm{LR}_{\mathrm{pG}}$ exhibited disordered conformations and LR $\alpha$ exhibited a more ordered conformation. However, with the increase in LPS concentration, $\mathrm{LR}_{\mathrm{pG}}$ and $\mathrm{LR} \alpha$ tended to gradually form an $\alpha$-helical structure. At the molar ratio peptide/LPS of 1:1, both LR $R_{\mathrm{pG}}$ and LR $\alpha$ began forming an $\alpha$-helical structure, indicating a similar binding ability to LPS.

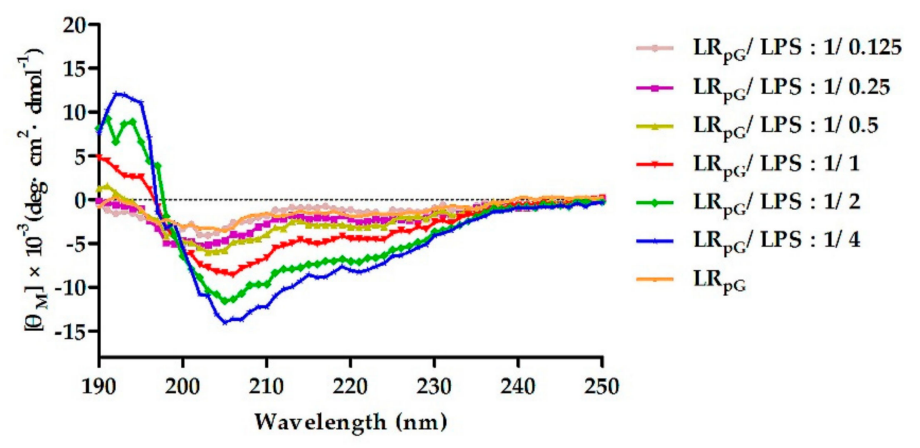

(a)

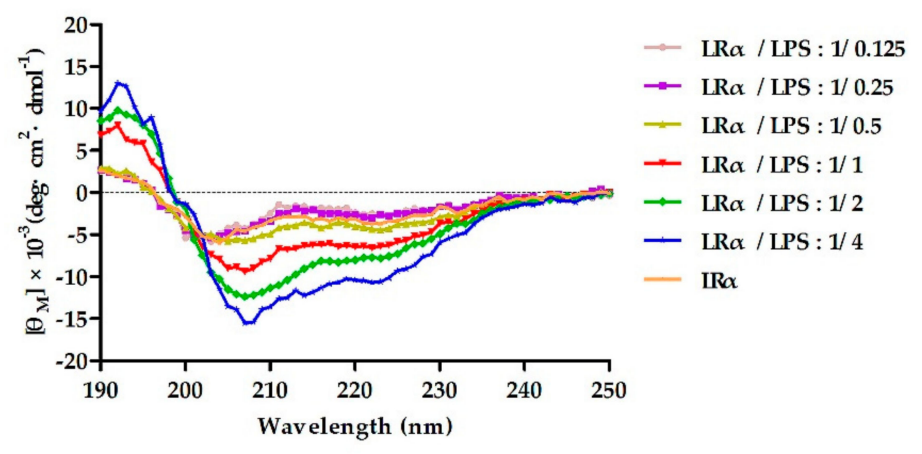

(b)

Figure 8. The circular dichroism (CD) spectra of (a) $L_{p G}$ and (b) $L R \alpha$ were dissolved in different concentrations of lipopolysaccharide (LPS), and the peptide/LPS molar ratio ranged from 1/0.125 to 1/4. The average value after three scans of every sample is shown. The CD spectrum of LPS was subtracted.

\subsubsection{Limulus Amoebocyte Lysate (LAL) Assay}

The chromogenic limulus amoebocyte lysate (LAL) assay was used to analyze the binding ability of the peptide to lipopolysaccharide (LPS). As shown in Figure 9, the activation of the LPS-mediated LAL coagulase was effectively inhibited by both $\mathrm{LR}_{\mathrm{pG}}$ and $\mathrm{LR} \alpha$ in a concentration-dependent manner. At low concentrations, the binding ability of $L_{p G}$ to LPS was much stronger than $L R \alpha$, but the difference tended to be diminished with the increase in peptide concentration.

\subsubsection{Endotoxin Neutralization Assay}

To detect the inhibitory effect of $L_{\mathrm{pG}}$ on the inflammatory response induced by LPS, the expression levels of two major inflammatory cytokines, tumor necrosis factor $\alpha$ (TNF- $\alpha$ ) and nitric oxide (NO), in the macrophage supernatant were measured. Cells without stimulation and cells stimulated with only LPS (100 ng. $\mathrm{mL}^{-1}$ ) were used as negative and positive controls, respectively. As can be seen from Figure 10, $\mathrm{LR}_{\mathrm{pG}}$ restrained the production of NO and TNF- $\alpha$ in a concentration-dependent manner and exhibited a significant inhibitory effect at $16 \mu \mathrm{M}$. The results showed that $\mathrm{LR}_{\mathrm{pG}}$ had a good neutralization ability in LPS. 


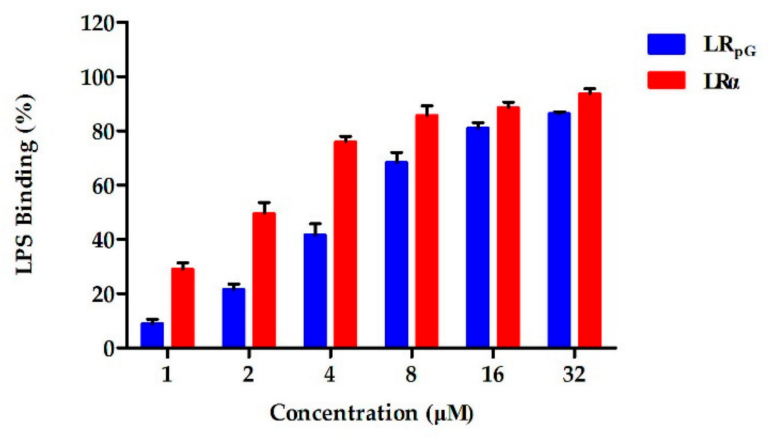

Figure 9. The binding ability of $\mathrm{LR}_{\mathrm{pG}}$ and $\mathrm{LR} \alpha$ to lipopolysaccharide (LPS), determined by limulus amoebocyte lysate (LAL) assay. The diagram is based on at least three independent experiments.

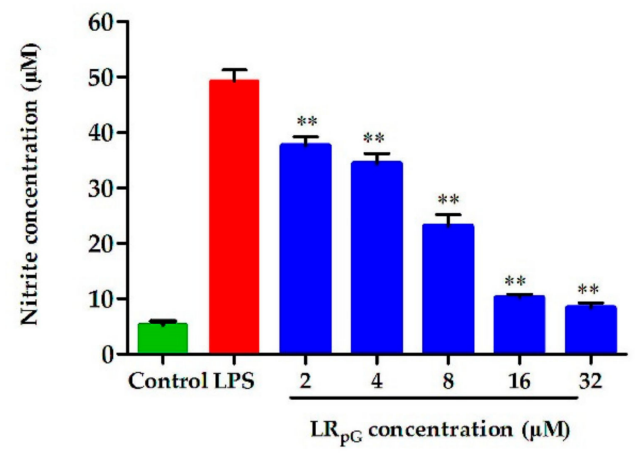

(a)

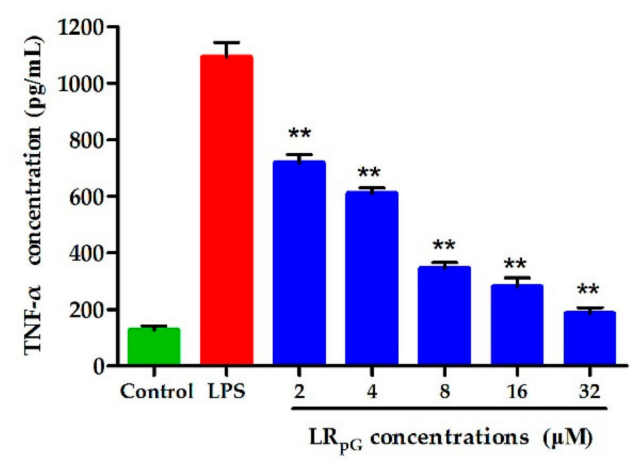

(b)

Figure 10. Effects of $\mathrm{LR}_{\mathrm{pG}}$ on the production of (a) nitric oxide (NO) and (b) tumor necrosis factor $\alpha$ (TNF- $\alpha$ ) in LPS-stimulated RAW 264.7 cells. The diagrams are based on the average of three independent experiments. ${ }^{* *} p<0.01$, compared to the positive group (only LPS-stimulated).

\section{Discussion}

Most AMPs have unique mechanisms of killing bacteria, mainly involving membrane breaking, which endows them with the potential to be alternatives to antibiotics [2]. However, the progress of natural AMPs for therapeutic application is seriously hindered by their inherent defects (such as manufacturing costs, cytotoxicity, poor stability etc.) $[2,8]$. To overcome these inherent shortcomings, in this study, six symmetric heptad repeat sequences were connected by a short loop, and the sequence was designed as XXRXXRRzzRRXXRXX-NH $\mathrm{N}_{2}$ (X represents $\mathrm{F}$, I, and L; zz represents GG or $\mathrm{pG}$ ).

The results of MICs indicated that the designed peptides had good antibacterial activity toward Gram-negative bacteria (Table 2). Compared to the single membrane and thick peptidoglycan layer of Gram-positive bacteria, the double-membrane structure of Gram-negative bacteria represents a weaker barrier; thus, Gram-negative bacteria are more sensitive to AMPs [17,21,24]. The antibacterial activity of AMPs can be affected by many factors. Previous studies demonstrated that a proper positive charge $(+6$ to +7$)$ was essential for antibacterial activity, but antibacterial activity was no longer increased when the positive charge of AMPs was beyond the threshold $[17,20]$. In this study, the positive charge of the designed peptides was set to +6 . Based on their hydrophobicity, the theoretical antibacterial activity of the designed peptides would be $\mathrm{IR}_{\mathrm{ZZ}}>\mathrm{FR}_{\mathrm{ZZ}}>\mathrm{LR}_{\mathrm{ZZ}}=\mathrm{LR} \alpha$; however, the result was $\mathrm{LR} \alpha>\mathrm{LR}_{\mathrm{ZZ}}>\mathrm{FR}_{\mathrm{ZZ}}>\mathrm{IR} \mathrm{ZZ}$. Combined with the results of CD, although both $\mathrm{LR}_{\mathrm{ZZ}}$ and $\mathrm{LR} \alpha$ had the tendency to form an $\alpha$-helical structure in membrane-mimetic environments, LR $\alpha$ 's tendency was stronger. One possible explanation is that the rigid loop $(p G)$ of $L_{Z Z Z}$ disrupted the $\alpha$-helical structure. Furthermore, we found that both $\mathrm{FR}_{\mathrm{ZZ}}$ and $\mathrm{IR}_{\mathrm{ZZ}}$ exhibited disordered conformations 
in membrane-mimetic environments. The result further confirmed the previous perspectives that the antibacterial activity of designed peptides is not only connected to the hydrophobicity of the peptides but also to the spatial stability of the secondary structure [25]. In addition, the antibacterial activity of $X R_{p G}$ was higher than that of $X R_{G G}$. Some papers confirmed that the rigid loop (pG), which promotes tightness in the hydrophobic center, has a better effect than the flexible loop (GG) [20].

However, the antimicrobial activity of AMPs is not the only criterion when evaluating their potential for clinical application. The hemolytic activity and cytotoxicity to mammalian cells are also major limiting factors $[26,27]$. Therefore, the cytotoxicity and hemolytic activity of the designed peptides were tested. At all examined concentrations, the designed peptides had much lower hemolysis and cytotoxicity (Figure 2), showing better cell selectivity compared to LR $\alpha$. This result may be due to the insertion of the central loop as previous papers reported. The cell selectivity of $\mathrm{XR}_{\mathrm{pG}}$ was better than that of $\mathrm{XR}_{\mathrm{GG}}$, which may be due to the rigid $\mathrm{pG}$ having a better effect on promoting cell selectivity than flexible GG [20]. As shown in Table 2, $\mathrm{LR}_{\mathrm{pG}}$ had a great balance between antibacterial activity and cytotoxicity, and it had higher cell selectivity.

In addition to the cell selectivity assays of AMPs, stability is also a major reason impeding AMPs from becoming therapeutic agents $[2,28,29]$. In this study, the effects of the physiological concentrations of salts, temperature, and $\mathrm{pH}$ on the antibacterial activity of the designed peptides were investigated. As shown in Table 3, in salt ions, the antimicrobial activity of $\mathrm{LR}_{\mathrm{pG}}$ against E. coli ATCC25922 was negligibly affected by all tested cations except for $\mathrm{Na}^{+}$. Previous reports suggested that a stable $\alpha$-helical structure helps salt tolerance [30]. However, the insertion of the loop (pG) structure into the sequence template still resulted in good salt stability in this study. The result was due to the loop (pG) promoting hydrogen bonding and hydrophobic interactions, thereby achieving the effect of salt tolerance [31]. The antibacterial activity of $\mathrm{LR}_{\mathrm{pG}}$ against E. coli ATCC25922 decreased because of the disruption of electrostatic interaction between $\mathrm{LR}_{\mathrm{pG}}$ and the cell membrane in the presence of $150 \mathrm{mM} \mathrm{Na}^{+}$[32]. For the clinical application of AMPs, thermal stability is very important since many foods and feed products need to be heated during processing [33]. $\mathrm{LR}_{\mathrm{pG}}$ exerted good thermal stability (Table 4) and could maintain antibacterial activity in different $\mathrm{pH}$ conditions.

Furthermore, $\mathrm{LR}_{\mathrm{pG}}$ exhibited a synergistic effect with streptomycin and additive effects with other antibiotics against E. coli ATCC25922 (Table 5). Some studies reported that the antibacterial effect of streptomycin and chloramphenicol involved acting on ribosomes, while ciprofloxacin acted on DNA gyrase, and cefotaxime acted on the cell membrane. In this study, $\mathrm{LR}_{\mathrm{pG}}$ acted on cell membranes to increase membrane permeability and promote antibiotic entry into cells [34,35]. The combination of $\mathrm{LR}_{\mathrm{pG}}$ and antibiotics improved the binding efficiency and ultimately enhanced the therapeutic efficacy. Therefore, $\mathrm{LR}_{\mathrm{pG}}$ can serve as an additive to decrease the dose of antibiotics.

In this study, we also compared a natural AMP (melittin) to $\mathrm{LR}_{\mathrm{pG}}$ in the $\mathrm{GM}_{\mathrm{MIC}}, \mathrm{MHC}_{10}, \mathrm{GM}_{\mathrm{SI}}$, and stability results. Although it exhibited a slightly better antibacterial activity than $\mathrm{LR}_{\mathrm{pG}}$, melittin had a strong hemolysis effect. By calculating the $\mathrm{GM}_{\mathrm{SI}}$ values $\left(\mathrm{MHC}_{10} / \mathrm{GM}_{\mathrm{MIC}}\right)$, we found that the $\mathrm{GM}_{\mathrm{SI}}$ of $\mathrm{LR}_{\mathrm{pG}}$ was 584 times higher than that of melittin. Furthermore, $\mathrm{LR}_{\mathrm{pG}}$ exerted a good conditional stability and additive effects with conventional antibiotics. Based on the results above, $\mathrm{LR}_{\mathrm{pG}}$ overcomes the main limiting factors of natural AMPs (such as melittin) and has the potential to develop into a therapeutic agent. Therefore, we further studied the antibacterial mechanism of $L_{\mathrm{pG}}$. Previous studies demonstrated that cationic AMPs combine with anions on the surface of bacteria via electrostatic action, and their hydrophobic amino acids are inserted into the bacterial cell membrane. Once the critical concentration is exceeded, the membrane breaks, and this ultimately leads to death of the bacteria [21,22]. $\mathrm{LR}_{\mathrm{pG}}$ firstly bound to the LPS of the outer membrane of E. coli ATCC25922 through electrostatic action (Figure 8), and then destroyed the cell membrane. Compared to the outer membrane, $\mathrm{LR}_{\mathrm{pG}}$ had a much weaker permeability to the inner membrane than $\mathrm{LR} \alpha$ (Figures 3 and 4 ). This result might be due to the decreased helical tendency of the $L_{\mathrm{pG}}$ as a result of the loop (pG), which was consistent with the previous papers showing that the helical tendency of AMPs was closely related to the permeability of bacterial inner membrane [20]. After breaking the impermeable 
barrier, $\mathrm{LR}_{\mathrm{pG}}$ interacted with the cytoplasmic membrane, resulting in pore and ion channel formation (Figure 5). SEM results directly confirmed that $\mathrm{LR}_{\mathrm{pG}}$ killed E. coli (Figure 6) by destroying the bacterial cell membranes and causing intracellular lysate leakage. In addition to the membrane mechanisms mentioned above, $\mathrm{LR}_{\mathrm{pG}}$ can bind to intracellular material DNA at a concentration much higher than the MIC (Figure 7), suggesting that $\mathrm{LR}_{\mathrm{pG}}$ cannot kill bacteria by DNA binding at the MIC. Furthermore, we found that the DNA binding ability of $L R_{p G}$ was relatively weaker than that of $L R \alpha$. One possible reason is that the $\alpha$-helical forming ability of $L R_{p G}$ was weaker than that of $L R \alpha$. In short, $L R_{p G}$ exerted its antibacterial effect by destroying the integrity of the bacterial cell membrane, causing leakage of the cellular content and binding to DNA through the cell membrane.

LPS is a crucial component of the outer membrane in Gram-negative bacteria [36]. Following bacterial death under the action of antibacterial agents, a large amount of LPS detaches from the cells and enters into the blood circulation of the body, activates the inflammatory signaling pathway, and releases inflammatory mediators such as NO and TNF- $\alpha[37,38]$. Previous studies showed that positively charged amphipathic AMPs had a strong LPS neutralization ability and were ideal candidates for anti-inflammatory drugs $[39,40]$. The LPS-induced inflammatory mediators NO and TNF- $\alpha$ were remarkably inhibited by $\mathrm{LR}_{\mathrm{pG}}$ in a concentration-dependent manner (Figure 10). Based on this study, $\mathrm{LR}_{\mathrm{pG}}$ has the potential to develop into an anti-inflammatory agent by blocking LPS-mediated inflammatory mediators.

\section{Materials and Methods}

\subsection{Materials}

Escherichia coli (E. coli) ATCC25922, E. coli K88, Pseudomonas aeruginosa (P. aeruginosa) ATCC27853, Salmonella Pullorum (S. Pullorum) NCTC5776, Klebsiella pneumoniae (K. pneumoniae) CMCC46117, Staphylococcus aureus (S. aureus) ATCC25923, S. aureus ATCC29213, methicillin-resistant S. aureus ATCC43300, and Enterococcus faecalis (E. faecalis) ATCC29212 were obtained from the pharmacology and toxicology laboratory of the College of Animal Science and Technology, Jilin Agricultural University (Changchun, China). HEK293T and RAW 264.7 cells were obtained from the College of Animal Science and Technology, Jilin Agricultural University (Changchun, China). The hRBCs were obtained from the Jilin Agricultural University Hospital.

Mueller-Hinton broth (MHB) powder and Mueller-Hinton agar (MHA) were purchased from GL Biochem (Shanghai, China). Bovine serum albumin (BSA), Triton X-100, and phosphate-buffered saline (PBS) solution were purchased from Solarbio (Beijing, China). O-nitrophenyl- $\beta$-D-galactopyranoside (ONPG), LPS from E. coli 0111 B4, diSC $3-5$, polymyxin B, 4-(2-hydroxyethyl) piperazine-1-ethanesulfonic acid (HEPES), and NPN were all purchased from Sigma-Aldrich (Shanghai, China). TransDetect Cell Counting Kit-8 (CCK-8) and Dulbecco's modified Eagle's medium with high glucose (DMEM) were purchased from TransGen Biotech (Beijing, China). Fetal bovine serum (FBS) was purchased from Gibco (Shanghai, China).

\subsection{Synthesis and Sequence Analysis of Peptides}

The designed peptides were sent to GL Biochem (Shanghai, China) for synthesis and purification. The purity of the peptide was determined by reverse-phase high-performance liquid chromatography on an analytical Kromasil $C_{18}$ column (Beijing, China). The purity of the peptide was over $95 \%$ (RP-HPLC). ESI-MS analysis was used to measure the molecular weight of designed peptides, and values were very close to the calculated values. The primary physical and chemical parameters of the designed peptides were measured online at http://web.expasy.org/compute_pi/. The hydrophobicity and relative hydrophobic moments were measured online at http://heliquest.ipmc.cnrs.fr/. 


\subsection{Spectroscopy}

The CD Spectroscopy of the designed peptides was detected on a J-810 spectropolarimeter (Jasco, Tokyo, Japan) at $25^{\circ} \mathrm{C}$. The final concentration of peptides in $10 \mathrm{mM}$ PBS (pH 7.4), 50\% TFE, and $30 \mathrm{mM}$ SDS was $150 \mu \mathrm{M}$. The experimental parameters were as follows: $10 \mathrm{~nm} \cdot \mathrm{min}^{-1}$ scanning rate, $1 \mathrm{~mm}$ path length, and 190-250 $\mathrm{nm}$ wavelength range. Each peptide was scanned an average of three times. The collected data were transformed to mean residue ellipticity as follows:

$$
\theta_{\mathrm{M}}=\frac{\theta_{\mathrm{obs}} \times 1000}{1 \times \mathrm{c} \times \mathrm{n}}
$$

where $\theta_{\mathrm{M}}$ represents the mean residue ellipticity $\left(\mathrm{deg} \cdot \mathrm{cm}^{2} \cdot \mathrm{dmol}^{-1}\right), \theta_{\text {obs }}$ represents the ellipticity correction of that measurement buffer at a given wavelength (mdeg), 1 represents the path length $(\mathrm{cm})$, $\mathrm{c}$ represents the peptide concentration $(\mathrm{mM})$, and $\mathrm{n}$ represents the number of amino residues.

\subsection{MIC Measurements}

The antimicrobial activity of the designed peptides was examined using the micro-dilution method described previously [29]. The bacteria were cultured for $16 \mathrm{~h}$ in $\mathrm{MHB}$ at $37^{\circ} \mathrm{C}$, and the microbial suspension was diluted to a final concentration of $10^{5}$ colony-forming units (CFU)/mL. Then, $50 \mu \mathrm{L}$ of MHB containing different concentrations peptides $(0.25-256 \mu \mathrm{M})$ was mixed with $50 \mu \mathrm{L}$ of bacterial solution, and the mixture was added to a 96-well plate. After incubation for $16 \mathrm{~h}$, MIC was examined by measuring the OD at $492 \mathrm{~nm}$ (Microplate reader, TECAN GENios F129004, Tecan, Salzburg, Austria). The assays were performed three times.

\subsection{Biocompatibility Assays}

The hemolytic activity was examined based on the method mentioned previously [22]. Briefly, the collected hRBCs were washed three times and diluted at $2 \%(v / v)$ with PBS (pH 7.4). Then, $100 \mu \mathrm{L}$ of hRBCs were put into each tube including $100 \mu \mathrm{L}$ of two-fold diluted peptides. The mixtures were centrifuged at $1000 \times \mathrm{g}$ for $3 \mathrm{~min}$. The OD value at $570 \mathrm{~nm}$ of the supernatant was measured, describing hemoglobin release (Microplate reader, TECAN GENios F129004, Tecan, Salzburg, Austria). For this assay, $1 \%$ Triton X-100-treated hRBCs were used as a positive control and untreated hRBCs were used as a negative control. $\mathrm{MHC}_{10}$ was defined as the peptide concentration that caused $10 \%$ hemolysis. The assays were performed three times.

The cytotoxicity was detected according to a CCK-8 assay as described previously. Briefly, RAW 264.7 and HEK293T cells were placed into 96-well plates at a density of $1.0-2.0 \times 10^{5}$, and then cultured for $16 \mathrm{~h}$ under conditions of $5 \% \mathrm{CO}_{2}$. Then, two-fold diluted peptides in DMEM were added to the plates. After $16 \mathrm{~h}$ of culturing, CCK- $8(10 \%, v / v)$ was put into each well containing cell culture, and mixtures were cultured for $2 \mathrm{~h}$. The cytotoxicity assay was examined by measuring the OD of the mixtures at $450 \mathrm{~nm}$ (Microplate reader, TECAN GENios F129004, Tecan, Salzburg, Austria). The assays were performed three times.

\subsection{Condition Sensitivity Assays}

The salt, temperature, and $\mathrm{pH}$ sensitivities of designed peptides were determined by MIC assay as described previously [40]. For the salt sensitivity assay, peptides were diluted in deionized water containing different salts, and mixed with E. coli ATCC25922 $\left(10^{5} \mathrm{CFU} / \mathrm{mL}\right)$. The final physiological concentrations of different salts were as follows: $150 \mathrm{mM} \mathrm{NaCl}, 4.5 \mathrm{mM} \mathrm{KCl}, 6 \mu \mathrm{M} \mathrm{NH}_{4} \mathrm{Cl}, 1 \mathrm{mM} \mathrm{MgCl}_{2}$, $8 \mu \mathrm{M} \mathrm{ZnCl}$, and $4 \mu \mathrm{M} \mathrm{FeCl}_{3}$. For temperature sensitivity, peptides were cooled on ice for $10 \mathrm{~min}$, and incubated at $37^{\circ} \mathrm{C}$ and $100{ }^{\circ} \mathrm{C}$ for $30 \mathrm{~min}$. For $\mathrm{pH}$ sensitivity, peptides were treated with different $\mathrm{pH}$ for $1 \mathrm{~h}$. Briefly, peptides were diluted in deionized water, and the $\mathrm{pH}$ of the solution was adjusted to 4.0, 6.0, 8.0, and 10.0 with $\mathrm{HCl}$ or $\mathrm{NaOH}$. The subsequent steps were the same as for the MIC measurements. These tests were performed three times. 


\subsection{Synergy with Conventional Antibiotics}

The combined antibacterial effect of peptides with other antibiotics was evaluated by checkerboard assay as described previously [31]. Briefly, peptides and antibiotics diluted two-fold were prepared at concentrations ranging from $1 / 8 \times$ MIC to $2 \times$ MIC. Subsequently, each peptide at the same concentration was added to the longitudinal column of wells, and each antibiotic at the same concentration was added to the horizontal row of wells. A suspension at $10^{5} \mathrm{CFU} / \mathrm{mL}$ was put into each well for $16 \mathrm{~h}$ at $37^{\circ} \mathrm{C}$. Each assay was performed three times. The fractional inhibitory concentration (FIC) index was calculated as follows:

$$
\text { FIC }=\frac{\text { MIC of drug A in combination }}{\text { MIC of drug A alone }}+\frac{\text { MIC of drug B in combination }}{\text { MIC of drug B alone }}
$$

where FIC $\leq 0.5$ denotes synergy, $0.5<$ FIC $\leq 1.0$ denotes additive, and $1.0<$ FIC $\leq 4.0$ denotes indifferent.

\subsection{Outer Membrane Permeability Assay}

The outer membrane permeability was examined using fluorescent dye NPN according to the method mentioned previously $[17,21,41]$. Briefly, E. coli ATCC25922 cells were washed three times and diluted to $10^{5} \mathrm{CFU} / \mathrm{mL}$ in $5 \mathrm{mM}$ HEPES buffer ( $\mathrm{pH} 7.4$, containing $5 \mathrm{mM}$ glucose). Then, the final concentration of $10 \mu \mathrm{M}$ NPN was added to the suspension, and incubated at room temperature in the dark for $30 \mathrm{~min}$. An equal volume of suspension and peptides at various concentrations were mixed in a black 96 -well plate. The fluorescence intensities of the samples were measured (emission $\lambda=420 \mathrm{~nm}$, excitation $\lambda=350 \mathrm{~nm}$ ) with an F4500 fluorescence spectrophotometer (Hitachi, Tokyo, Japan). Polymyxin B $(10 \mu \mathrm{g} / \mathrm{mL})$ with strong outer membrane permeability was used as a positive control. Values were converted to percentage NPN uptake using the following equation:

$$
\text { NPN uptake }(\%)=\frac{F_{\text {obs }}-F_{0}}{F_{100}-F_{0}} \times 100
$$

where $\mathrm{F}_{\mathrm{obs}}$ is the observed fluorescence of NPN with E. coli ATCC25922 cells at a given peptide concentration, $F_{0}$ is the initial fluorescence of NPN with E. coli ATCC25922 cells, and $\mathrm{F}_{100}$ is the fluorescence of NPN with E. coli ATCC25922 cells with the addition of $10 \mu \mathrm{g} / \mathrm{mL}$ polymyxin B.

\subsection{Inner Membrane Permeability Assay}

The inner membrane permeabilization was determined by measuring the cytoplasm $\beta$-galactosidase activity according to the method mentioned previously [21]. In short, an equal volume of the suspension of E. coli ATCC25922 cells was washed three times and diluted to an $\mathrm{OD}_{600}$ of 0.05 with $10 \mathrm{mM}$ PBS (containing $1.5 \mathrm{mM} \mathrm{ONPG);} \mathrm{then,} \mathrm{the} \mathrm{suspension} \mathrm{was} \mathrm{put} \mathrm{into} \mathrm{each} \mathrm{well}$ of a 96-well plate and cultured with $0.5 \times$ MIC to $4 \times$ MIC peptides at $37{ }^{\circ} \mathrm{C}$. The OD at $420 \mathrm{~nm}$ (Microplate reader, TECAN GENios F129004, Tecan, Salzburg, Austria) was recorded for $40 \mathrm{~min}$ every 5 min eight times. The method was used to detect the permeabilization of the inner membrane through the reflection of the ONPG influx into the cells.

\subsection{Cytoplasmic Membrane Depolarization Assay}

DiSC $_{3}-5$, a membrane potential-sensitive fluorescent dye, was used to assess the ability of the peptides to disrupt the cytoplasmic membrane as previously described, [42]. Briefly, E. coli ATCC25922 in the mid-log phase was washed three times and diluted to an $\mathrm{OD}_{600}$ of 0.05 with $5 \mathrm{mM}$ HEPES buffer (containing $20 \mathrm{mM}$ glucose and $100 \mathrm{mM} \mathrm{KCl}$ ); then, the mixture of E. coli ATCC25922 and $0.5 \times$ MIC to $4 \times$ MIC peptides was mixed with diSC $_{3}-5$ (final concentration of $0.4 \mu \mathrm{M}$ ) at $37^{\circ} \mathrm{C}$ for $1 \mathrm{~h}$. The fluorescence changes from 0 to $1500 \mathrm{~s}$ were recorded at the emission wavelength $(\lambda=670 \mathrm{~nm})$ and excitation wavelength $(\lambda=622 \mathrm{~nm})$ (Fluorescence Spectrophotometer, F4500, Hitachi, Tokyo, Japan). 


\subsection{Scanning Electron Microscopy}

E. coli ATCC25922 cells in the mid-log phase were washed three times and diluted to $10^{7}$ $\mathrm{CFU} / \mathrm{mL}$ in $10 \mathrm{mM}$ PBS. The bacterial suspension and peptide ( $1 \times \mathrm{MIC})$ were added to 24 -well plates containing polylysine-treated glass slides. The bacteria untreated by peptide were used as a control. After incubation, the bacterial suspension was removed, and the treatment method with polylysine-glass slides was repeated. Then, the polylysine-treated glass slides were fixed with glutaraldehyde $(2.5 \%)$ at $4{ }^{\circ} \mathrm{C}$ for $12 \mathrm{~h}$ and dehydrated with a series of graded ethanol solutions for $20 \mathrm{~min}$. The polylysine-treated glass slides were transferred into a mixture $(v: v=1: 1)$ of pure alcohol and tertiary butanol for $15 \mathrm{~min}$, and then placed into pure tertiary butanol for $15 \mathrm{~min}$. Finally, the samples were treated using a critical point dryer with liquid $\mathrm{CO}_{2}$, and then scanned by a S-3400N SEM (Hitachi, Tokyo, Japan) after coating with gold-palladium.

\subsection{DNA Binding Assay}

The DNA binding assays were determined according to gel retardation experiments described previously [17]. Briefly, $400 \mathrm{ng}$ of genomic DNA (E. coli ATCC25922) was mixed with 0.5 to $256 \mu \mathrm{M}$ peptide in a binding buffer (50 $\mathrm{\mu g} / \mathrm{mL}$ BSA, $1 \mathrm{mM}$ ethylene diamine tetraacetic acid (EDTA), $20 \mathrm{mM} \mathrm{KCl}$, $10 \mathrm{mM}$ Tris- $\mathrm{HCl}(\mathrm{pH}=8.0), 5 \%$ glycerol, and $1 \mathrm{mM}$ dithiothreitol) for $60 \mathrm{~min}$ at $37^{\circ} \mathrm{C}$. Subsequently, the samples were examined by $1 \%$ agarose gel electrophoresis.

\subsection{LPS Binding Assay}

The ability of peptides to bind LPS was detected on a J-810 spectropolarimeter at $25^{\circ} \mathrm{C}$. Briefly, concentration of LPS ranged from 37.5-600 $\mu \mathrm{M}$, diluted using the double dilution method. The final concentration of peptides in the LPS solution was $150 \mu \mathrm{M}$. The experimental parameters were the same as in Section 4.3.

\subsection{LAL Assay}

Peptide neutralization was evaluated using a quantitative chromogenic limulus amoebocyte lysate (LAL) assay (Xiamen, China) [43]. Briefly, 1 endotoxin unit (EU) of LPS was incubated with two-fold serial dilutions of peptides at $37^{\circ} \mathrm{C}$ for $60 \mathrm{~min}$; then, $100 \mu \mathrm{L}$ of LAL reagent was added to the mixtures. After additional incubation for $15 \mathrm{~min}$ at $37^{\circ} \mathrm{C}, 100 \mu \mathrm{L}$ of chromogenic substrate solution was put into the tubes. Subsequently, the mixtures were incubated for another $10 \mathrm{~min}$ at $37^{\circ} \mathrm{C}$ before adding $500 \mu \mathrm{L}$ of azo reagent solutions $(1,2$, and 3$)$ in turn. The data were examined by measuring the OD value at $545 \mathrm{~nm}$ (Microplate reader, TECAN GENios F129004, Tecan, Salzburg, Austria).

\subsection{Endotoxin Neutralization Assay}

RAW 264.7 cells were put into 24 -well plates at a density of 1.0-2.0 $\times 10^{5}$ cells/well and stimulated with LPS $(100 \mathrm{ng} / \mathrm{mL})$ with $(1-64 \mu \mathrm{M})$ or without peptide. After incubating for $24 \mathrm{~h}$ at $37^{\circ} \mathrm{C}$ in $5 \% \mathrm{CO}_{2}$, the supernatants were collected for analysis of the NO production using Griess reagent and TNF- $\alpha$ levels using ELISA based on the manufacturer's protocol. The cells treated with LPS only and untreated cells were set as the positive and negative controls, respectively.

\subsection{Statistical Analysis}

ANOVA was used to analyze the data through the SPSS 18.0 software (IBM, Chicago, IL, USA). Quantitative data were expressed as the mean \pm standard deviation. A $p$-value $<0.01$ was considered to have statistical significance.

\section{Conclusions}

In this study, we designed peptides based on the sequence template XXRXXRRzzRRXXRXX-NH where $X$ represents a hydrophobic amino acid (F, I, and L) and zz represents the loop (GG or pG). 
The designed peptides effectively enhanced cell selectivity because of the introduction of the loop (GG or $\mathrm{pG})$. Among them, $\mathrm{LR}_{\mathrm{pG}}(\mathrm{X}: \mathrm{L}, \mathrm{zz}: \mathrm{pG})$ showed the highest average therapeutic index $\left(\mathrm{GM}_{\mathrm{TI}}=73.1\right)$, with better conditional stability, and it had an additive effect with conventional antibiotics. The antibacterial mechanism study demonstrated that $\mathrm{LR}_{\mathrm{pG}}$ first destroyed the integrity of the bacterial cell membrane, caused leakage of the cellular content, then entered the cell and bound to the DNA, and ultimately led to bacterial death. Furthermore, $\mathrm{LR}_{\mathrm{pG}}$ also had an obvious impact on anti-inflammatory ability. These results indicated that the design and optimization of natural AMPs in this study will be helpful in improving the clinical application of AMPs.

Supplementary Materials: Supplementary materials can be found at http://www.mdpi.com/1422-0067/21/3/1140/s1.

Author Contributions: Conceptualization, B.J.; funding acquisition, H.M.; supervision, H.M. and X.J.; project administration, H.M. and X.J.; investigation, Z.W., Y.W., Z.P., and L.K.; validation, Y.Z., X.W., and I.M. All authors have read and agreed to the published version of the manuscript.

Funding: This work was supported by the National Natural Science Foundation of China (Grant number: 31572574, 31872519 and 31572555), the National Key Research and Development Plan (Grant number: 2017YFD0501401), the Theme Guidance Project of Development of Science and Technology of Jilin Province (Grant number: 20160204002NY), the Natural Science Foundation of Jilin Province (Grant number: 20180101003JC), the Jilin Programs for Technology Research and Development (Grant number: 20170101025JC and 20170101021JC), and the Jilin Department of Education Programs for Science and Technology Research (Grant number: 201441).

Conflicts of Interest: The authors declare that no conflict of interest.

$\begin{array}{ll}\text { Abbreviations } \\ \text { AMPs } & \text { antimicrobial peptides } \\ \text { CD } & \text { circular dichroism } \\ \text { MIC } & \text { minimal inhibitory concentration } \\ \text { TI } & \text { theoretical index } \\ \text { hRBCs } & \text { human red blood cells } \\ \text { E. coli } & \text { Escherichia coli } \\ \text { FICI } & \text { fractional inhibitory concentration index } \\ \text { SEM } & \text { scanning electron microscopy } \\ \text { LPS } & \text { lipopolysaccharide }\end{array}$

\section{References}

1. Van Boeckel, T.P.; Brower, C.; Gilbert, M.; Grenfell, B.T.; Levin, S.A.; Robinson, T.P.; Teillant, A.; Laxminarayan, R. Global trends in antimicrobial use in food animals. Proc. Natl. Acad. Sci. USA 2015, 112, 5649-5654. [CrossRef]

2. Wang, J.J.; Dou, X.J.; Song, J.; Lyu, Y.F.; Zhu, X.; Xu, L.; Li, W.Z.; Shan, A.S. Antimicrobial peptides: Promising alternatives in the post feeding antibiotic era. Med. Res. Rev. 2019, 39, 831-859. [CrossRef] [PubMed]

3. Tellez, G.A.; Zapata, J.A.; Toro, L.J.; Henao, D.C.; Bedoya, J.P.; Rivera, J.D.; Trujillo, J.Y.; Rivas-Santiago, B.; Hoyos, R.O.; Castano, J.C. Identification, characterization, immunolocalization, and biological activity of lucilin peptide. Acta Trop. 2018, 185, 318-326. [CrossRef] [PubMed]

4. Chen, C.X.; Chen, Y.C.; Yang, C.; Zeng, P.; Xu, H.; Pan, F.; Lu, J.R. High selective performance of designed antibacterial and anticancer peptide amphiphiles. ACS Appl. Mater. Interfaces 2015, 7, 17346-17355. [CrossRef] [PubMed]

5. Omardien, S.; Brul, S.; Zaat, S.A. Antimicrobial activity of cationic antimicrobial peptides against gram-positives: Current progress made in understanding the mode of action and the response of bacteria. Front. Cell Dev. Biol. 2016, 4, 111. [CrossRef]

6. Zhang, Y.H.; Chen, T.W.; Pan, Z.M.; Sun, X.B.; Yin, X.; He, M.; Xiao, S.Y.; Liang, H.J. Theoretical insights into the interactions between star-shaped antimicrobial polypeptides and bacterial membranes. Langmuir. 2018, 34, 13438-13448. [CrossRef]

7. Melo, M.N.; Ferre, R.; Castanho, M.A. Antimicrobial peptides: Linking partition, activity and high membrane-bound concentrations. Nat. Rev. Microbiol. 2009, 7, 245-250. [CrossRef] 
8. Ong, Z.Y.; Wiradharma, N.; Yang, Y.Y. Strategies employed in the design and optimization of synthetic antimicrobial peptide amphiphiles with enhanced therapeutic potentials. Adv. Drug Deliv. Rev. 2014, 78, 28-45. [CrossRef]

9. Tripathi, A.K.; Kumari, T.; Tandon, A.; Sayeed, M.; Afshan, T.; Kathuria, M.; Shukla, P.K.; Mitra, K.; Ghosh, J.K. Selective phenylalanine to proline substitution for improved antimicrobial and anticancer activities of peptides designed on phenylalanine heptad repeat. Acta Biomater. 2017, 57, 170-186. [CrossRef]

10. Ahmad, A.; Azmi, S.; Srivastava, R.M.; Srivastava, S.; Pandey, B.K.; Saxena, R.; Bajpai, V.K.; Ghosh, J.K. Design of nontoxic analogues of cathelicidin-derived bovine antimicrobial peptide BMAP-27: The role of leucine as well as phenylalanine zipper sequences in determining its toxicity. Biochemistry 2009, 48, 10905-10917. [CrossRef]

11. Asthana, N.; Yadav, S.P.; Ghosh, J.K. Dissection of antibacterial and toxic activity of melittin: A leucine zipper motif plays a crucial role in determining its hemolytic activity but not antibacterial activity. J. Biol. Chem. 2004, 279, 55042-55050. [CrossRef] [PubMed]

12. Kumar, A.; Tripathi, A.K.; Kathuria, M.; Shree, S.; Tripathi, J.K.; Purshottam, R.K.; Ramachandran, R.; Mitra, K.; Ghosh, J.K. Single Amino acid substitutions at specific positions of the heptad repeat sequence of piscidin-1 yielded novel analogs that show low cytotoxicity and in vitro and in vivo antiendotoxin activity. Antimicrob. Agents Chemother. 2016, 60, 3687-3699. [CrossRef] [PubMed]

13. Srivastava, R.M.; Srivastava, S.M.; Singh, M.; Bajpai, V.K.; Ghosh, J.K. Consequences of alteration in leucine zipper sequence of melittin in its neutralization of lipopolysaccharide-induced proinflammatory response in macrophage cells and interaction with lipopolysaccharide. J. Biol. Chem. 2012, 287, 1980-1995. [CrossRef] [PubMed]

14. Dong, N.; Ma, Q.Q.; Shan, A.S.; Lv, Y.F.; Hu, W.N.; Gu, Y.; Li, Y.Z. Strand length-dependent antimicrobial activity and membrane-active mechanism of arginine- and valine-rich $\beta$-hairpin-like antimicrobial peptides. Antimicrob. Agents Chemother. 2012, 56, 2994-3003. [CrossRef]

15. Chou, S.L.; Shao, C.X.; Wang, J.J.; Shan, A.S.; Xu, L.; Dong, N.; Li, Z.Y. Short, multiple-stranded $\beta$-hairpin peptides have antimicrobial potency with high selectivity and salt resistance. Acta Biomater. 2016, 30, 78-93. [CrossRef]

16. Dong, N.; Chou, S.L.; Li, J.W.; Xue, C.Y.; Li, X.R.; Chen, B.J.; Shan, A.S. Short symmetric-end antimicrobial peptides centered on $\beta$-turn amino acids unit improve selectivity and stability. Front. Microbiol. 2018, 27, 2832. [CrossRef]

17. Wang, J.J.; Chou, S.L.; Xu, L.; Zhu, X.; Dong, N.; Shan, A.S.; Chen, Z. High specific selectivity and membrane-active mechanism of the synthetic centrosymmetric $\alpha$-helical peptides with gly-gly pairs. Sci. Rep. 2015, 5, 15963. [CrossRef]

18. Chou, S.L.; Wang, J.J.; Shang, L.; Akhtar, M.U.; Wang, Z.H.; Shi, B.M.; Feng, X.J.; Shan, A.S. Short, symmetric-helical peptides have narrow-spectrum activity with low resistance potential and high selectivity. Biomater. Sci. 2019, 7, 2394-2409. [CrossRef]

19. Ma, Z.; Yang, J.; Han, J.Z.; Gao, L.; Liu, H.X.; Lu, Z.X.; Zhao, H.Z.; Bie, X.M. Insights into the antimicrobial activity and cytotoxicity of engineered $\alpha$-helical peptide amphiphiles. J. Med. Chem. 2016, 59, 10946-10962. [CrossRef]

20. Shao, C.X.; Tian, H.T.; Wang, T.Y.; Wang, Z.H.; Chou, S.L.; Shan, A.S.; Chen, B.J. Central $\beta$-turn increases the cell selectivity of imperfectly amphipathic $\alpha$-helical peptides. Acta Biomater. 2018, 69, 243-255. [CrossRef]

21. Dong, N.; Wang, C.S.; Zhang, T.T.; Zhang, L.; Xue, C.Y.; Feng, X.J.; Bi, C.P.; Shan, A.S. Bioactivity and bactericidal mechanism of histidine-rich $\beta$-hairpin peptide against Gram-negative bacteria. Int. J. Mol. Sci. 2019, 20, 3954. [CrossRef] [PubMed]

22. Shao, C.X.; Li, W.Z.; Tan, P.; Shan, A.S.; Dou, X.J.; Ma, D.Y.; Liu, C.Y. Symmetrical modification of minimized dermaseptins to extend the spectrum of antimicrobials with endotoxin neutralization potency. Int. J. Mol. Sci. 2019, 20, 1417. [CrossRef] [PubMed]

23. Kumar, P.; Kizhakkedathu, J.N.; Straus, S.K. Antimicrobial peptides: Diversity, mechanism of action and strategies to improve the activity and biocompatibility in vivo. Biomolecules 2018, 8, 4. [CrossRef] [PubMed]

24. Zelezetsky, I.; Tossi, A. Alpha-helical antimicrobial peptides-using a sequence template to guide structure-activity relationship studies. Biochim. Biophys. Acta 2006, 1758, 1436-1449. [CrossRef] 
25. Takahashi, D.; Shukla, S.K.; Prakash, O.; Zhang, G. Structural determinants of host defense peptides for antimicrobial activity and target cell selectivity. Biochimie 2010, 92, 1236-1241. [CrossRef]

26. Kumar, A.; Mahajan, M.; Awasthi, B.; Tandon, A.; Harioudh, M.K.; Shree, S.; Singh, P.; Shukla, P.K.; Ramachandran, R.; Mitra, K.; et al. Piscidin-1-analogs with double L- and D-lysine residues exhibited different conformations in lipopolysaccharide but comparable anti-endotoxin activities. Sci. Rep. 2017, 7, 39925. [CrossRef]

27. Lee, J.K.; Park, S.C.; Hahm, K.S.; Park, Y. A helix-PXXP-helix peptide with antibacterial activity without cytotoxicity against MDRPA-infected mice. Biomaterials 2014, 35, 1025-1039. [CrossRef]

28. Zhu, X.; Zhang, L.C.; Wang, J.; Ma, Z.; Xu, W.; Li, J.P.; Shan, A.S. Characterization of antimicrobial activity and mechanisms of low amphipathic peptides with different $\alpha$-helical propensity. Acta Biomater. 2015, 18, 155-167. [CrossRef]

29. Wang, J.J.; Chou, S.L.; Yang, Z.Y.; Yang, Y.; Wang, Z.H.; Song, J.; Dou, X.J.; Shan, A.S. Combating drug-resistant fungi with novel imperfectly amphipathic palindromic peptides. J. Med. Chem. 2018, 61, 3889-3907. [CrossRef]

30. Park, I.Y.; Cho, J.H.; Kim, K.S.; Kim, Y.B.; Kim, M.S.; Kim, S.C. Helix stability confers salt resistance upon helical antimicrobial peptides. J. Biol. Chem. 2004, 279, 13896-13901. [CrossRef]

31. Jin, Y.; Hammer, J.; Pate, M.; Zhang, Y.; Zhu, F.; Zmuda, E.; Blazy, J. Antimicrobial activities and structures of two linear cationic peptide families with various amphipathic $\beta$-sheet and $\alpha$-helical potentials. Antimicrob. Agents Chemother. 2005, 49, 4957-4964. [CrossRef] [PubMed]

32. Arouri, A.; Dathe, M.; Blume, A. The helical propensity of KLA amphipathic peptides enhances their binding to gel-state lipid membranes. Biophys. Chem. 2013, 180, 10-21. [CrossRef] [PubMed]

33. Ma, Q.Q.; Dong, N.; Shan, A.S.; Lv, Y.F.; Li, Y.Z.; Chen, Z.H.; Cheng, B.J.; Li, Z.Y. Biochemical property and membrane-peptide interactions of de novo antimicrobial peptides designed by helix-forming units. Amino Acids 2012, 43, 2527-2536. [CrossRef]

34. Khara, J.S.; Wang, Y.; Ke, X.Y.; Liu, S.; Newton, S.M.; Langford, P.R.; Yang, Y.Y.; Ee, P.L. Anti-mycobacterial activities of synthetic cationic $\alpha$-helical peptides and their synergism with rifampicin. Biomaterials 2014, 35, 2032-2038. [CrossRef]

35. Liu, Y.F.; Xia, X.; Xu, L.; Wang, Y.Z. Design of hybrid $\beta$-hairpin peptides with enhanced cell specificity and potent anti-inflammatory activity. Biomaterials 2013, 34, 237-250. [CrossRef] [PubMed]

36. Hancock, R.E.; Haney, E.F.; Gill, E.E. The immunology of host defence peptides: Beyond antimicrobial activity. Nat. Rev. Immunol. 2016, 16, 321-334. [CrossRef]

37. Cohen, J.; Vincent, J.L.; Adhikari, N.K.; Machado, F.R.; Angus, D.C.; Calandra, T.; Jaton, K.; Giulieri, S.; Delaloye, J.; Opal, S.; et al. Sepsis: A roadmap for future research. Lancet Infect. Dis. 2015, 15, 581-614. [CrossRef]

38. Zong, X.; Song, D.; Wang, T.; Xia, X.; Hu, W.; Han, F.; Wang, Y. LFP-20, a porcine lactoferrin peptide, ameliorates LPS-induced inflammation via the MyD88/NF- $\mathrm{B}$ and MyD88/MAPK signaling pathways. Dev. Comp. Immunol. 2015, 52, 123-131. [CrossRef]

39. Khara, J.S.; Obuobi, S.; Wang, Y.; Hamilton, M.S.; Robertson, B.D.; Newton, S.M.; Yang, Y.Y.; Langford, P.R.; Ee, P.L.R. Disruption of drug-resistant biofilms using, de novo, designed short $\alpha$-helical antimicrobial peptides with idealized facial amphiphilicity. Acta Biomater. 2017, 57, 103-114. [CrossRef]

40. Wang, J.J.; Song, J.; Yang, Z.Y.; He, S.Q.; Yang, Y.; Feng, X.J.; Dou, X.J.; Shan, A.S. Antimicrobial peptides with high proteolytic resistance for combating gram-negative bacteria. J. Med. Chem. 2019, 62, 2286-2304. [CrossRef]

41. Dong, N.; Zhu, X.; Chou, S.; Shan, A.S.; Li, W.Z.; Jiang, J.G. Antimicrobial potency and selectivity of simplified symmetricend peptides. Biomaterials 2014, 27, 8028-8039. [CrossRef] [PubMed]

42. Lv, X.T.; Ma, Q.Q.; Zhu, D.D.; Shao, C.X.; Lv, Y.F.; Shan, A.S. The C-terminal sequences of porcine thrombin are active as antimicrobial peptides. Chem. Biol. Drug Des. 2016, 88, 905-914. [CrossRef] [PubMed]

43. Sun, Y.; Dong, W.B.; Sun, L.; Ma, L.J.; Shang, D.J. Insights into the membrane interaction mechanism and antibacterial properties of chensinin-1b. Biomaterials 2015, 37, 299-311. [CrossRef] [PubMed]

(C) 2020 by the authors. Licensee MDPI, Basel, Switzerland. This article is an open access article distributed under the terms and conditions of the Creative Commons Attribution (CC BY) license (http://creativecommons.org/licenses/by/4.0/). 